\title{
FORMULASI KEBIJAKAN PELAKSANAAN PERLINDUNGAN KAWASAN SEMPADAN SUNGAI DI KOTA BANJARMASIN
}

\author{
Muhammad Ananta Firdaus, Risni Ristiawati, Salma Saphira \\ Fakultas Hukum, Universitas Lambung Mangkurat, Banjarmasin \\ ananta.firdaus@ulm.ac.id
}

\begin{abstract}
Abstrak
Penelitian ini bertujuan untuk mendapatkan formulasi kebijakan dalam penataan kawasan sempadan sungai di Kota Banjarmasin. Pemerintah Kota Banjarmasin mengupayakan pencegahan penggunaan sempadan sungai untuk kawasan yang belum terganggu oleh peruntukan lain dan upaya penertiban bagi pelanggaran sempadan sungai yang telah digunakan untuk peruntukan lain melalui Peraturan Daerah Kota Banjarmasin Nomor 31 Tahun 2012 tentang Penetapan, Pengaturan, Pemanfaatan Sempadan Sungai dan Bekas Sungai. Penelitian ini menggunakan pendekatan socio legal, yaitu dengan menggunakan peraturan perundang-undangan yang mengatur tentang sempadan sungai, kemudian diperkuat dengan studi lapangan menggunakan teknik purposive accidental sampling. Hasil dari penelitian ini adalah telah terjadinya alih fungsi lahan sempadan sungai di Kota Banjarmasin menjadi permukiman penduduk yang disebabkan ketidaktahuan masyarakat tentang ketentuan-ketentuan mendirikan bangunan di kawasan sempadan sungai. Implementasi Perda mengalami beberapa hambatan, pertama dikarenakan kondisi eksisting dimana masyarakat Kota Banjarmasin secara lokal budaya memang masyarakat yang bertumbuh di pinggiran sungai, dan kedua karena pengaturan jarak sempadan sungai yang cukup lebar dinilai kurang sesuai dengan kondisi geografis Kota Banjarmasin dengan wilayah yang sempit namun dialiri oleh banyak anak sungai.
\end{abstract}

Kata kunci : Implementasi Kebijakan; Perlindungan; Sempadan Sungai

\section{THE FORMULATION OF POLICY FOR THE IMPLEMENTATION OF THE PROTECTION OF RIVER BORDER AREAS IN THE CITY OF BANJARMASIN}

\begin{abstract}
This study aims to obtain a policy formulation in structuring river border areas in Banjarmasin City. The Banjarmasin City Government seeks to prevent the use of river borders for areas that have not been disturbed by other designations and efforts to curb violations of river borders that have been used for other purposes through the Banjarmasin City Regional Regulation Number 31 of 2012 concerning Stipulation, Regulation, Utilization of River Borders and Former Rivers. This study uses a socio-legal approach, namely by using the laws and regulations governing river boundaries, then strengthened by field studies using purposive accidental sampling techniques. The result of this research is that there has been a conversion of river borderland in Banjarmasin City into residential areas due to public ignorance about the provisions for constructing buildings in the river border area. The implementation of the Regional Regulation encountered several obstacles, firstly due to the existing conditions where the people of Banjarmasin City were culturally local people who grew up on the banks of the river, and secondly because the regulation of the distance of the river border which was wide enough was considered to be incompatible with the geographical conditions of the City of Banjarmasin with a narrow area but flowed by the river. many tributaries.

Keywords: Implementation Of Policy; Protection; River Border
\end{abstract}




\section{PENDAHULUAN}

\section{A. Latar Belakang}

Kota Banjarmasin disebut sebagai kota seribu sungai, memiliki ciri khas dengan banyaknya masyarakat yang bertempat tinggal di pinggiran sungai. Banjarmasin tidak memiliki sumber daya alam berupa bahan tambang, tidak juga memiliki hutan sehingga tidak ada kayu dan hasil hutan lainnya. Yang ada hanya aliran sungai yang melimpah, sedikit ada persawahan yang kini sudah berubah fungsi menjadi kawasan perkotaan. ${ }^{1}$ Manfaat sungai bagi masyarakat Banjarmasin antara lain adalah untuk kebutuhan sehari-hari, sumber irigasi, pembangkit listrik, sebagai sarana perjalanan transportasi, dan lokasi pariwisata. Akan tetapi keberadaan sungai tersebut akan sangat berbahaya jika tidak dilakukan pengendalian serta pengawasan pembangunan pada sempadan sungai dan badan sungai, karena dapat menyebabkan terjadinya penyempitan badan sungai, bahkan bisa menimbulkan bahaya-bahaya lain seperti banjir, erosi, dan sedimentasi.

Perkembangan kota merupakan konsekuensi logis dari proses urbanisasi yang terus-menerus membawa dampak yang serius bagi kehidupan kota. Dengan kondisi lahan perkotaan yang terbatas, menyebabkan semakin tingginya kepadatan bangunan dengan arah persebaran yang tidak beraturan, sehingga menimbulkan tekanan pada kawasan sekitarnya, terutama pada kawasan tepi air sungai atau yang lebih umum dengan istilah bantaran sungai. Persebaran bangunan yang tidak terkendali memberi dampak pada kawasan bantaran sungai dengan timbulnya bangunan-bangunan di sekitar daerah bantaran sungai. Ditambah lagi, dengan semakin tingginya harga lahan perkotaan dan disertai lemahnya perekonomian sebagian besar masyarakat, memaksa penduduk memanfaatkan lahan kosong seperti daerah bantaran sungai dengan membangun permukiman liar. ${ }^{2}$

Pemanfaatan lahan yang tidak terkoordinasi dan lepas dari pengawasan pemerintah, memacu semakin tidak terkendalinya alih fungsi lahan menjadi kawasan terbangun yang membuat kawasan bantaran sungai mengalami pemanfaatan lahan yang tidak sesuai, dengan adanya bangunan di sepanjang bagian tepi kanan dan kiri sungai. Padahal peraturan kawasan bantaran sungai menempati batas lahan yang semestinya tidak boleh didirikan bangunan. Gangguan pada sempadan yang merupakan kawasan lindung dari sungai tersebut. akan menimbulkan permasalahan seperti hilangnya kawasan lindung sabuk hijau. ${ }^{3}$ Sabuk hijau merupakan penghijauan yang ditanami pepohonan yang ditata dan

\footnotetext{
${ }^{1}$ Muhammad Ananta Firdaus, "Pelaksanaan Peraturan Daerah Tentang Larangan Kegiatan Pada Bulan Ramadhan Di Kota Banjarmasin," Badamai Law Journal 3, no. 1 (2018): 132.

2 Ira Mentayani, "Identitas Dan Eksistensi Permukiman Tepi Sungai Di Banjarmasin," in Prosiding Seminar Nasional Lingkungan Lahan Basah (Banjarmasin: Lembaga Penelitian dan Pengabdian kepada Masyarakat, Universitas Lambung Mangkurat, 2019), 498.

3 Herliyani Farial Agoes, "Studi Inventarisasi Sungai Yang Tidak Produktif Di Kota Banjarmasin," Jurnal INTEKNA : Informasi Teknik Dan Niaga 11, no. 2 (2011): 158.
} 
dirancang sesuai dengan fungsi ekologinya sebagai pengendali tata air, pencegah erosi, sebagai paru-paru lingkungan, fungsi fisiknya sebagai peneduh untuk menciptakan kesejukan lingkungan, serta fungsi estetisnya adalah untuk menciptakan keindahan dan keasrian lingkungan. Lokasi sabuk hijau yang terletak di daerah sempadan sungai disyaratkan tidak diperbolehkan ada bangunan (gedung) permanen, semi permanen, dan non permanen. Pemanfaatan ruang pada kawasan sepadan sungai, umumnya mengalami kecenderungan tidak terkontrolnya persebaran bangunan pada daerah aliran sungai yang berdampak pada penurunan kualitas sungai. Selain itu, masyarakat yang menempati bantaran sungai umumnya membuang sampah dan limbah rumah tangga langsung ke badan/air sungai. Padahal, sungai merupakan salah satu sumber air bersih yang penting dalam kehidupan. ${ }^{4}$

Banjarmasin yang dikenal melegenda sebagai "kota seribu sungai" kini berubah menjadi "kota seribu masalah". Permasalahan yang dialami pada sungaisungai di Banjarmasin khususnya adalah hilangnya sungai yang berubah menjadi daerah pemukiman penduduk, baik di atas sungai atau di pinggirnya (sempadan). Sebagian sungai-sungai yang masih ada, tapi kondisinya sangat memprihatinkan karena sungai yang kotor, tercemar dengan limbah keluarga, timbunan sampah, limbah industri, tersumbat sampah, dan lain-lain. Sungai-sungai tidak dapat difungsikan lagi sebagaimana mestinya, seperti untuk menampung air hujan, untuk sarana transportasi, atau bahkan untuk kepentingan rekreasi (wisata sungai). Oleh karena itu, selain fungsionalitas (nilai manfaat) sungai, hal lain yang tampak hilang adalah nilai artistik sungai sebagai daya tarik wisata. Hal tersebut karena sungaisungai di Banjarmasin tidak hanya menjadi tidak indah, tapi juga tidak bersih. ${ }^{5}$

Adapun penelitian ini sendiri dilakukan untuk melengkapi hasil penelitian yang pernah ada sebelumnya tentang kawasan sempadan sungai di Kota Banjarmasin. Penelitian yang pertama berjudul "Identifikasi Dan Problematika Penggunaan Lahan Lingkungan Bantaran Sungai Terhadap Peraturan Pemerintah Dan Daerah" oleh Muhlis (2013). Penelitian ini meneliti tentang kondisi daerah bantaran atau pesisir sungai yang dijadikan tempat bermukim masyarakat dan penggunaan lainnya, serta faktor-faktor yang menyebabkan kesesuaian dan ketidaksuaian bantaran sungai di Banjarmasin dengan kebijakan pemerintah dalam menjaga dan menata wilayah sekitar bantaran sungai. Kelebihan dari penelitian ini adalah mengidentifikasi kesesuaian perda dan peraturan lainnya tentang pengaturan kawasan sempadan sungai di Kota Banjarmasin. Sedangkan kekurangannya adalah

\footnotetext{
4 Irwan Yudha Hadinata and Bani Noor Muchamad, "Studi Penyusunan Dan Penentuan Sempadan Sungai Di Kota Banjarmasin,” Jurnal Kebijakan Pembangunan 13, no. 1 (2018): 5.

5 Amar Rizqi Afdholy, "Tipomorfologi Permukiman Tepian Sungai Martapura Kota Banjarmasin," Local Wisdom: Jurnal Ilmiah Kajian Kearifan Loka 9, no. 1 (2017): 34https://jurnal.unmer.ac.id/index.php/lw/article/, https://doi.org/https://doi.org/10.26905/lw.v9i1.1865.
} 
penelitian ini belum memberikan solusi bagaimana formulasi kebijakan yang tepat untuk mengatur tentang kawasan sempadan sungai, mengingat perda yang mengatur tentang hal tersebut baru mulai berlaku setahun sebelum penelitian ini dibuat.

Penelitian yang kedua adalah "Pengelolaan Sungai Menurut Peraturan Daerah Kota Banjarmasin Nomor 2 Tahun 2007" oleh Sidqi (2016). Penelitian ini hanya mendeskripsikan tentang pengaturan mengenai pengelolaan sungai menurut Peraturan Daerah Kota Banjarmasin Nomor 2 Tahun 2007 serta sanksi atas pelanggaran. Perda ini juga bisa dikatakan sudah ketinggalan zaman, sebab ada dua buah perda terbaru yaitu Peraturan Daerah Kota Banjarmasin Nomor 31 Tahun 2012 tentang Penetapan, Pengaturan, Pemanfaatan Sempadan Sungai Dan Bekas Sungai, serta Peraturan Daerah Kota Banjarmasin Nomor 15 Tahun 2016 tentang Upaya Peningkatan Pengelolaan Sungai.

Kemudian penelitian yang ketiga adalah "Studi Penyusunan Dan Penentuan Sempadan Sungai di Kota Banjarmasin” oleh Hadinata (2018). Penelitian ini mengangkat isu lokalitas dan budaya dalam penentuan sempadan yang seharusnya tidak dapat diterapkan secara menyeluruh untuk Kota Banjarmasin. Kelebihan penelitian ini menjelaskan tentang tujuh tipologi umum sebagai perwakilan pemanfaatan ruang bantaran sungai di Kota Banjarmasin, dimana sungai tidak hanya dipandang sebagai jaringan ekologis namun lebih kepada saujana budaya atau cultural landscape yang memuat aktivitas, riuh suasana, dan keterkaitan masyarakat terhadap sungai. Sementara kekurangan dari penelitian ini adalah belum menyentuh aspek hukum, yaitu tentang perlindungan hukum terhadap kawasan sempadan sungai di Kota Banjarmasin, implementasi perda serta penegakkan sanksinya.

Penelitian ini mengkaji tentang "Formulasi Kebijakan Pelaksanaan Perlindungan Kawasan Sempadan Sungai di Kota Banjarmasin" berusaha merangkum problematika yang ditemukan dari hasil penelitian-penelitian terdahulu, kemudian melakukan analisis masalah agar dapat menemukan formulasi kebijakan yang tepat dalam mengatasi permasalahan-permasalahan tersebut. Sebab yang menjadi masalah klasik dari implementasi peraturan yang ada adalah adanya benturan antara aturan dengan lokal budaya masyarakat Banjar dan juga sistem perekonomian masyarakat. Kelebihan lain dari penelitian ini adalah merupakan penelitian yang berusaha menemukan model pengelolaan sempadan sungai sebagai strategi pengembangan wilayah. Penelitian ini juga tentunya memiliki tujuan akhir, yaitu : Dapat memberikan solusi dengan membantu merumuskan konsep yang tepat untuk penataan kawasan sempadan sungai di Kota Banjarmasin, agar Pemerintah Kota Banjarmasin dapat meningkatkan fisik kawasan sempadan sungai, serta menciptakan kebijakan tentang pengelolaan kawasan sempadan sungai di Kota Banjarmasin dengan berbasis pada kelestarian lingkungan dan penunjang 
pengembangan pariwisata. Membantu Pemerintah Kota Banjarmasin dalam melakukan sosialisasi kebijakan daerah terkait pengelolaan dan pemanfaatan kawasan sempadan sungai, serta memberikan pemahaman kepada masyarakat tentang larangan mendirikan bangunan di kawasan sempadan sungai di Kota Banjarmasin.

\section{B. Permasalahan}

Dari apa yang disebutkan di atas, bahwa pemerintah mengupayakan pencegahan menggunakan sempadan sungai untuk kawasan yang belum terganggu oleh peruntukan lain dan upaya penertiban bagi pelanggaran sempadan sungai yang telah digunakan untuk peruntukan lain. Meski pengaturan kawasan sempadan sungai telah tercantum dalam Peraturan Daerah Kota Banjarmasin, namun efektivitasnya masih kurang, sebab masih banyak pemukiman ilegal di kawasan sempadan sungai. Masih kurangnya kesadaran dari masyarakat akan pentingnya sungai dan sempadan sungai, serta masih kurangnya upaya pemeritah dalam pengaturan kawasan sempadan sungai menyebabkan pengembalian lahan pemukiman ilegal untuk dijadikan sempadan sungai masih belum optimal. Begitu banyak permasalahan dalam pengelolaan sungai di Kota Banjarmasin termasuk masalah tata ruang, khususnya tentang kawasan sempadan sungai dan pemukiman di sekitar sungai yang sangat mempengaruhi kondisi sungai saat ini.

\section{Metode Penelitian/Landasan Teoritis}

Metode yang digunakan dalam penyusunan penelitian tentang "Formulasi Kebijakan Pelaksanaan Perlindungan Kawasan Sempadan Sungai di Kota Banjarmasin" ini adalah dengan pendekatan socio legal, yaitu dengan memanfaatkan bantuan ilmu sosial dalam melakukan penelitian hukum, agar diperoleh kesesuaian antara das sollen dan das sein. Hal ini untuk memenuhi kebutuhan akan penjelasan lebih rinci dan cermat terhadap persoalan hukum secara lebih bermakna dengan melakukan perbandingan antara law in book dengan law in action.

Metodologinya sendiri dilakukan dengan cara mengaplikasikan perspektif keilmuan sosial terhadap studi hukum, diantaranya sosiologi hukum dan antropologi hukum, dengan cara mengupas dan menuntaskan terlebih dahulu soal kerangka normatif suatu masalah. Penelitian tentang "Formulasi Kebijakan Pelaksanaan Perlindungan Kawasan Sempadan Sungai di Kota Banjarmasin" ini tentunya tidak dapat dipisahkan dengan kenyataan bahwa sungai bagi masyarakat Banjarmasin adalah merupakan budaya sekaligus kearifan lokal, dimana masyarakat Banjarmasin bertumbuh di pinggiran sungai dan hampir seluruh aktivitas masyarakat yang tidak terlepas dari sungai. Oleh karena itu, penelitian ini akan melihat bagaimana implementasi Perda yang dibuat serta efektivitasnya terkait dengan kenyataan sosiologi hukum dan antropologi hukum yang ada pada masyarakat Banjarmasin. 
Konsekuensi dari penelitian hukum yang menggunakan paradigma sociolegal sebagai paradigma utama adalah menggunakan penggabungan metode yuridis normatif dengan metode sosiologis kualitatif. Penelitian dengan pendekatan yuridis normatif (documentary research), artinya menguji dan mengkaji data sekunder, yaitu menggunakan data kepustakaan berupa hukum positif yang berhubungan dengan peraturan perundang-undangan yang mengatur tentang sempadan sungai.

Untuk memperkuat hasil penelitian dilakukan pula studi lapangan untuk mengumpulkan data primer untuk memperoleh data yang dibutuhkan dalam rangka ketajaman analisis. Studi lapangan dilaksanakan dengan teknik wawancara dan observasi. Informan diperoleh dengan menggunakan teknik purposive accidental sampling mengingat karakteristik populasi penelitian yang tidak dapat diketahui secara pasti jumlahnya, tersebar dalam wilayah geografi yang relatif luas. Data primer diperoleh secara langsung dari informan dengan merujuk pada pedoman wawancara terstruktur yang disusun untuk memperoleh data terkait dengan lahan basah khususnya kawasan sempadan sungai di Kota Banjarmasin. Data yang dikumpulkan dari penelitian lapangan adalah data primer tentang segala sesuatu yang ada kaitannya dengan masalah yang diteliti. Dalam memperoleh data tersebut ditentukan wilayah dan obyek penelitian.

\section{HASIL DAN PEMBAHASAN}

\section{A. Kewenangan Pemerintah Daerah Dalam Penataan Kawasan Sempadan Sungai}

Dalam rangka penyelenggaraan pemerintahan daerah sesuai dengan amanat Undang Undang Dasar Negara Republik Indonesia Tahun 1945, pemerintahan daerah yang mengatur dan mengurus sendiri urusan pemerintahan menurut asas otonomi dan tugas pembantuan, diarahkan untuk mempercepat terwujudnya kesejahteraan masyarakat melalui peningkatan, pelayanan, pemberdayaan, dan peran serta masyarakat, serta peningkatan daya saing daerah dengan memperhatikan prinsip demokrasi, pemerataan, keadilan, keistimewaan dan kekhususan suatu daerah dalam sistem Negara Kesatuan Republik Indonesia. Untuk efisiensi dan efektivitas penyelenggaraan pemerintahan daerah, perlu ditingkatkan dengan lebih memperhatikan aspek-aspek hubungan antar susunan pemerintahan dan antar pemerintahan. daerah, potensi dan keanekaragaman daerah, peluang dan tantangan persaingan global dengan memberikan kewenangan yang seluas-luasnya kepada daerah disertai dengan pemberian hak dan kewajiban menyelenggarakan otonomi daerah dalam kesatuan sistem penyelenggaraan pemerintahan negara.

Daerah sebagai satu kesatuan masyarakat hukum yang mempunyai otonomi berwenang mengatur dan mengurus daerahnya sesuai aspirasi dan kepentingan masyarakatnya sepanjang tidak bertentangan dengan tatanan hukum nasional dan kepentingan umum. Dalam rangka memberikan ruang yang lebih luas kepada daerah untuk mengatur dan mengurus kehidupan warganya, maka pemerintah pusat 
dalam membentuk kebijakan harus memperhatikan kearifan lokal, dan sebaliknya daerah ketika membentuk kebijakan daerah baik dalam bentuk peraturan daerah (Perda) maupun kebijakan lainnya hendaknya juga memperhatikan kepentingan nasional. Dengan demikian akan tercipta keseimbangan antara kepentingan nasional yang sinergis dan tetap memperhatikan kondisi, kekhasan, dan kearifan lokal dalam penyelenggaraan pemerintahan secara keseluruhan.

Berdasarkan undang-undang tentang pemerintahan daerah yang mengatur tentang segala sesuatu yang fundamental yang berkaitan dengan aspek pemerintahan daerah diantaranya berkenaan dengan adanya kewenangan penyelenggaraaan urusan dilakukan oleh pemerintah daerah bersama-sama dengan dewan perwakilan rakyat daerah setempat berdasarkan asas-asas dalam otonomi daerah, dengan tetap berpegangan pada Negara Kesatuan Republik Indonesia (NKRI) dan UUD 1945. Termasuk dalam hal ini pemerintah daerah diberikan kewenangan dalam hal adalah penyelenggaran pemerintahan sesuai dengan kewenangan yang telah diberikan oleh UU dengan tetap melibatkan Dewan Perwakilan Rakyat Daerah (DPRD) sebagai salah satu mitra penyelenggara pemerintahan di daerah.

Otonomi daerah merupakan hak, wewenang, dan kewajiban daerah untuk mengatur dan mengurus rumah tangganya berdasarkan NKRI. Dimana asas otonomi merupakan prinsip pokok dalam penyelenggaraan pemerintahan daerah diantaranya adalah asas desentralisasi, dekonsentrasi dan tugas pembantuan. Desentralisasi adalah "penyerahan sebagian urusan pemerintahan pusat kepada pemerintah daerah, sedangkan dekonsentrasi adalah pelimpahan sebagian urusan pemerintahan yang menjadi kewenangan pemerintah pusat kepada gubernur sebagai wakil pemerintah pusat kepada instansi vertikal di wilayah tertentu, dan/atau kepada gubernur dan bupati/walikota sebagai penanggung jawab urusan pemerintahan umum". Sementara itu tugas pembantuan merupakan penugasan dari pemerintah pusat kepada daerah otonom untuk melaksanakan sebagian urusan pemerintahan yang menjadi kewenangan pemerintah pusat, atau dari pemerintah daerah provinsi kepada daerah kabupaten/kota untuk melaksanakan sebagian urusan pemerintahan yang menjadi kewenangan daerah provinsi.

Sebagai daerah otonom maka, pemerintah daerah provinsi, kabupaten dan kota, berwenang untuk membuat peraturan daerah dan peraturan kepala daerah, guna menyelenggarakan urusan otonomi daerah dan tugas pembantuan. Peraturan daerah (Perda) ditetapkan oleh kepala daerah, setelah mendapat persetujuan bersama Dewan Perwakilan Rakyat (DPRD). Substansi atau muatan materi Perda adalah penjabaran dari peraturan perundang-undangan yang tingkatannya lebih tinggi, dengan memperhatikan ciri khas masing-masing daerah, dan substansi 
materi tidak boleh bertentangan dengan kepentingan umum dan/atau peraturan perundangan yang lebih tinggi. ${ }^{6}$

Kewenangan menurut F.A.M. Stroink dan J.G. Steenbeek menyebutnya sebagai konsep inti dalam hukum tata negara dan hukum administrasi, "Het begrip bevoegdheid is dan ook een kernbegrip in het staat-en administratief recht".7 Karena itulah, kewenangan memiliki kedudukan penting dalam kajian hukum tata negara dan hukum administrasi.

Menurut H.D. Stout, "Bevoegdheid is een begrip uit het bestuurlijke organisatierecht, wat kan worden omschreven als het geheel van regels dat betrekking heft op de verkrijging en uitoefening van bestuursrechtelijke bevoegdheden door publikerechtelijke rechtsubjecten in het besturrechtelijke rechtsverkeer" (wewenang merupakan pengertian yang berasal dari hukum organisasi pemerintahan, yang dapat dijelaskan sebagai keseluruhan aturan-aturan yang berkenaan dengan perolehan dan penggunaan wewenang pemerintahan oleh subjek hukum publik di dalam hubungan hukum publik). ${ }^{8}$

Selanjutnya menurut F.P.C.L Tonnaer, "Overheidsbevoegdheid word in dit verband opgevat als het vermogwn om positief recht vast te stellen en Aldus rechtsbetrekkingen tussen burgers anderling en tussen overhead en te scheppen" (kewenangan pemerintah dalam kaitan ini dianggap sebagai kemampuan untuk melaksanakan hukum positif, dan dengan begitu, dapat diciptakan hubungan hukum antar pemerintah dengan warga negara). ${ }^{9}$

Bagir Manan berpendapat bahwa wewenang dalam bahasa hukum tidak sama dengan kekuasaan (macht). Kekuasaan hanya menggambarkan hak untuk berbuat atau tidak berbuat. Dalam hukum, wewenang sekaligus berarti hak dan kewajiban (rechten en plichten). Dalam kaitannya dengan otonomi daerah, hak mengandung pengertian kekuasaan untuk mengatur sendiri (zelfregelen) dan mengelola sendiri (zelfbestuuren), sedangkan kewajiban secara horizontal berarti kekuasaan untuk menyelenggarakan pemerintahan sebagaimana mestinya. Vertikal berarti kekuasaan untuk menjalankan pemerintahan dalam satu tertib ikatan pemerintahan negara secara keseluruhan. ${ }^{10}$

Dalam Undang-undang Nomor 23 Tahun 2014 tentang Pemerintahan Daerah Pasal 9 ayat (1), urusan pemerintahan terdiri atas urusan pemerintahan absolut, urusan pemerintahan konkuren, dan urusan pemerintahan umum, yang kemudian dalam ayat (3) dijelaskan kembali bahwa urusan pemerintahan konkuren sebagaimana dimaksud pada ayat (1) adalah urusan pemerintahan yang dibagi

\footnotetext{
${ }^{6}$ Siswanto Sunarno, Hukum Pemerintahan Daerah (Jakarta: Sinar Grafika, 2006).

7 Ridwan HR, Hukum Administrasi Negara (Jakarta: PT Rajagrafindo Persada, 2006).

${ }^{8} \mathrm{HR}$.

9 HR.

${ }_{10}$ Bagir Manan, "Wewenang Provinsi, Kabupaten, Dan Kota Dalam Rangka Otonomi Daerah,” in Seminar Nasional (Bandung: Fakultas Hukum Universitas Padjajaran, 2000), 1-2.
} 
antara pemerintah pusat dan daerah provinsi dan daerah kabupaten/kota. Dan pada ayat (4), urusan pemerintahan konkuren yang diserahkan ke daerah menjadi dasar pelaksanaan otonomi daerah. Sedangkan urusan yang menjadi urusan pemerintah pusat menurut Undang-undang Nomor 23 Tahun 2014 pada Pasal 10 ayat (1) adalah

1. Politik luar negeri;

2. Pertahanan;

3. Keamanan;

4. Yustisi;

5. Moneter dan Fiskal Nasional; dan

6. Agama.

Berdasarkan hal tersebut di atas, maka Kaho menyatakan bahwa "Prinsip otonomi yang luas, nyata dan bertanggung jawab adalah otonomi daerah itu harus merupakan otonomi yang bertanggung jawab, dalam arti bahwa pemberian otonomi itu harus benar-benar sejalan dengan tujuannya, yaitu melancarkan pembangunan yang tersebar di pelosok negara dan serasi atau tidak bertentangan dengan peraturan-peraturan, pembinaan politik dan kesatuan bangsa serta menjadi hubungan yang serasi antara pemerintah pusat dan pemerintah daerah atas dasar keutuhan negara kesatuan". Otonomi daerah memberikan peluang yang besar kepada daerah untuk berkembang. Di mana peluang besar tersebut muncul karena adanya penyerahan urusan yang diberikan oleh pemerintah pusat kepada pemerintah daerah.

Dengan adanya otonomi daerah menurut Winarsa Surya Adisubrata, daerah diberikan kewenangan untuk : Pertama, Hak untuk mengatur dan mengurus rumah tangga sendiri; Kedua, Wewenang untuk mengatur daerah sendiri; Ketiga, Kewajiban untuk mengatur rumah tangga sendiri. ${ }^{11}$ Jadi, otonomi merupakan pemberian kebebasan untuk mengurus rumah tangga sendiri, tanpa mengabaikan kedudukan pemerintah daerah sebagai aparat pemerintah pusat untuk menyelenggarakan tugas-tugas yang ditugaskan kepadanya. dengan demikian, kebutuhan otonomi dalam pemerintahan daerah dimaksudkan untuk memperbesar kewenangan mengatur dan mengurus rumah tangga sendiri dan memperkecil intervensi pemerintah pusat dalam urusan rumah tangga daerah. ${ }^{12}$

Berdasarkan hal tersebut, otonomi daerah dapat dipandang sebagai cara untuk mewujudkan penyelenggaraan pemerintah yang efektif, efisien dan berwibawa yang mewujudkan pelayanan kepada masyarakat dalam meningkatkan kesejahteraan masyarakat dengan memperhatikan prinsip demokrasi, pemerataan, keadilan, keistimewaan dan kekhususan suatu daerah dalam sistem Negara

11 Manan.

12 Manan. 
Kesatuan Republik Indonesia. Adanya pemberian kewenangan oleh undangundang kepada pemerintah daerah provinsi maupun pemerintah daerah kabupaten/kota tersebut, maka semakin menunjukkan penerapan asas legalitas di Indonesia, bahwa maknanya adalah Dat het bestuur aan de wet is onderworpen (bahwa pemerintah tunduk kepada undang-undang) atau Het legalitieitsbegisel houdt in dat alle (algemene) de burgers bindede bepalingen op de wet moeten berusten (bahwa semua ketentuan yang mengikat warga negara harus didasarkan pada undang-undang $)^{13}$, dalam hal ini termasuk juga setiap pemberian kewenangan yang diberikan oleh undang-undang otonomi daerah kepada pemerintah daerah kabupaten/kota.

Penerapan asas legalitas dalam bidang pemerintahan, khususnya di era otonomi daerah diharapkan akan dapat menciptakan kepastian hukum. Dengan kata lain, setiap penyelenggaraan pemerintahan harus memiliki legitimasi, yaitu kewenangan yang diberikan oleh undang-undang. Dengan demikian, substansi dari penerapan asas legalitas adalah wewenang, yakni Het vermogen tot het verrichten van be paalde rechtshandelingen (kemampuan untuk melakukan tindakan-tindakan hukum tertentu). ${ }^{14}$ Menurut Bagir Manan, wewenang dalam bahasa hukum tidak sama dengan kekuasaan (macht). Kekuasaan hanya menggambarkan hak untuk berbuat atau tidak berbuat. Sementara dalam hukum, wewenang sekaligus berarti hak dan kewajiban (rechten en plichten). Kaitannya dengan otonomi daerah, hak mengandung pengertian kekuasaan untuk mengatur sendiri (zalfregelen) dan mengelola sendiri (zelfbesturen), sedangkan kewajiban secara horizontal berarti kekuasaan untuk menyelenggarakan pemerintahan sebagaimana mestinya. Vertikal berarti kekuasaan untuk menjalankan pemerintahan dalam satu tertib ikatan pemerintahan negara secara keseluruhan. ${ }^{15}$ Dalam hal ini, pemberian otonomi daerah kepada daerah provinsi dan kabupaten/kota tidak dapat dilepaskan keberadaannya dari Negara Kesatuan Republik Indonesia, sehingga memberikan implikasi hukum bahwa setiap kebijakan yang ada di daerah harus tetap seiring dan sejalan dengan kepentingan nasional.

Sesuai dengan amanat Undang Undang Dasar Negara Republik Indonesia Tahun 1945 Pasal 18, pemerintah daerah berwenang untuk mengatur dan mengurus sendiri urusan pemerintahan menurut asas otonomi dan tugas pembantuan. Pemberian otonomi luas kepada daerah diarahkan untuk mempercepat terwujudnya kesejahteraan masyarakat melalui peningkatan pelayanan, pemberdayaan dan peran serta masyarakat. Di samping itu, melalui otonomi luas, daerah diharapkan mampu meningkatkan daya saing dengan memperhatikan prinsip demokrasi, pemerataan,

\footnotetext{
13 HR, Hukum Administrasi Negara.

14 Salim HS and Elis Septiana Nurbani, Penerapan Teori Hukum Pada Penelitian Tesis Dan Disertasi (Jakarta: PT Rajagrafindo Persada, 2013).

15 Manan, "Wewenang Provinsi, Kabupaten, Dan Kota Dalam Rangka Otonomi Daerah."
} 
keadilan, keistimewaan dan kekhususan serta potensi dan keanekaragaman daerah dalam sistem Negara Kesatuan Republik Indonesia.

Prinsip otonomi daerah menggunakan prinsip otonomi seluas-luasnya, dalam arti daerah diberikan kewenangan mengurus dan mengatur semua urusan pemerintahan di luar yang menjadi urusan pemerintah yang ditetapkan dalam undang-undang. Daerah memiliki kewenangan membuat kebijakan daerah untuk memberi pelayanan, peningkatan peran serta, prakarsa, dan pemberdayaan masyarakat yang bertujuan pada peningkatan kesejahteraan rakyat. Dengan begitu, maka peraturan daerah sebagai salah satu instrumen hukum (produk hukum daerah) yang dilahirkan untuk memberikan aturan terhadap kebijakan ataupun aspirasi yang muncul di daerah, yang kemudian diterapkan dalam daerah masing-masing (provinsi dan kabupaten/kota).

Undang-undang Nomor 23 Tahun 2014 menyatakan bahwa Perda ditetapkan oleh kepala daerah setelah mendapat persetujuan bersama DPRD. Hal ini menunjukkan bahwa Perda sebagai instrumen hukum yang dibuat oleh pemerintah daerah (dalam hal ini kepala daerah dan DPRD) untuk mengatur daerahnya. Mengatur (regeling) disini maksudnya adalah Perda yang dilahirkan adalah Perda yang berfungsi untuk mengatur publik (masyarakat) dalam wilayahnya masingmasing, sesuai dengan pemberian kewenangan yang diberikan oleh undangundang.

Pemerintah Kota Banjarmasin telah menerbitkan Peraturan Daerah Nomor 31 Tahun 2012 tentang Penetapan, Pengaturan, Pemanfaatan Sempadan Sungai dan Bekas Sungai. Peraturan daerah merupakan sebuah peraturan perundang-undangan yang dibenarkan oleh undang-undang, dibentuk oleh dewan perwakilan rakyat daerah dengan persetujuan bersama kepala daerah. Materi muatan peraturan daerah adalah seluruh materi muatan dalam rangka penyelenggaraan otonomi daerah dan tugas pembantuan, dan menampung kondisi khusus daerah. Suatu peraturan daerah isinya tidak boleh bertentangan dengan peraturan lain yang lebih tinggi di atasnya.

Peraturan perundang-undangan merupakan hukum tertulis yang dibuat oleh pejabat yang berwenang, berisi aturan-aturan tingkah laku yang bersifat abstrak dan mengikat umum. ${ }^{16}$ Istilah perundang-undangan (legislation atau gesetzgebung) mempunyai dua pengertian yang berbeda, yaitu :

1. Perundang-undangan sebagai sebuah proses pembentukan atau proses membentuk peraturan-peraturan negara, baik di tingkat pusat maupun di tingkat daerah;

2. Perundang-undangan sebagai segala peraturan negara, yang merupakan hasil proses pembentukan peraturan-pearaturan, baik di tingkat pusat maupun ditingkat daerah.

16 Aziz Syamsudin, Proses Dan Teknik Perundang-Undangan (Jakarta: Sinar Grafika, 2011). 
Dalam tataran pemerintahan lokal, aspek hukum dalam penyelenggaraan pemerintahan daerah di era otonomi merupakan salah satu aspek yang sangat terkait dengan keseluruhan aktivitas penyelenggaraan pemerintah daerah. Pemerintah Daerah, dengan hubungan kemitraan antara DPRD selaku badan legislatif daerah dengan kepala daerah beserta jajarannya selaku lembaga eksekutif daerah, tercermin dari produk hukum yang dihasilkan, yakni berupa peraturan daerah baik pada tingkat provinsi maupun kabupaten/kota.

Undang-undang Nomor 12 Tahun 2011 tentang Pembentukan Peraturan perundang-undangan, terdapat dua pengertian tentang peraturan daerah, yakni peraturan daerah provinsi dan peraturan daerah kabupaten/kota. Peraturan daerah provinsi adalah peraturan perundang-undangan yang dibentuk oleh dewan perwakilan rakyat daerah provinsi dengan persetujuan bersama gubernur. Sedang peraturan daerah kabupaten/kota adalah peraturan perundang-undangan yang dibentuk oleh dewan perwakilan rakyat daerah kabupaten/kota dengan persetujuan bersama bupati/walikota. peraturan daerah dibentuk dalam rangka penyelenggaraan otonomi daerah provinsi/kabupaten/kota dan tugas pembantuan, serta merupakan penjabaran lebih lanjut dari peraturan perundangan-undangan yang lebih tinggi dengan memperhatikan ciri khas masing-masing daerah.

Peraturan daerah sebagai salah satu bentuk peraturan perundang-undangan merupakan bagian dari pembangunan sistem hukum nasional. Peraturan daerah yang baik dapat terwujud apabila didukung oleh metode dan standar yang tepat, sehingga memenuhi teknis pembentukan peraturan perundang-undangan, sebagaimana diatur dalam Undang-undang Nomor 12 Tahun 2011 tentang Pembentukan Peraturan Perundang-undangan. Peraturan Daerah dalam pembentukannya tunduk pada asas maupun teknik dalam penyusunan perundangundangan yang telah ditentukan. Landasan sebagai pijakan, alasan atau latar belakang perundangan-undangan itu harus jelas. Bagir Manan menyatakan, ada 4 landasan yang digunakan dalam menyusun perundang-undangan agar menghasilkan perundang-undangan yang tangguh dan berkualitas, yakni landasan yuridis, sosiologis, filosofis dan politis. ${ }^{17}$

\section{B. Implementasi Pengaturan Kawasan Sempadan Sungai Di Kota Banjarmasin}

Penyerahan sebagian besar kewenangan pemerintah kepada pemerintah daerah telah menempatkan pemerintah daerah sebagai ujung tombak pembangunan nasional, dalam rangka menciptakan kemakmuran rakyat secara adil dan merata. Dalam kaitan ini peran dan dukungan daerah dalam rangka pelaksanaan peraturan

17 W. Riawan Tjandra and Kresno Budi Harsono, Legislatif Drafting Teori Dan Teknik Pembuatan Peraturan Daerah (Yogyakarta: Universitas Admajaya, 2009). 
perundang-undangan sangat strategis, khususnya dalam membuat peraturan daerah dan peraturan lainnya sesuai dengan ketentuan peraturan perundang-undangan.

Peraturan daerah merupakan peraturan perundang-undangan yang dibentuk oleh dewan perwakilan rakyat daerah (DPRD) provinsi atau kabupaten/kota dengan persetujuan bersama kepala daerah. Peraturan Daerah sebagaimana peraturan perundang-undangan lainnya memiliki fungsi untuk mewujudkan kepastian hukum. Peraturan perundang-undangan harus memenuhi syarat-syarat tertentu, antara lain konsisten dalam perumusan, dimana dalam peraturan perundang-undangan yang sama harus terpelihara hubungan sistemik antara kaidah-kaidahnya, kebakuan susunan dan bahasa, dan adanya harmonisasi antara berbagai peraturan perundangundangan, hal ini mengingat materi muatan peraturan daerah provinsi dan peraturan daerah kabupaten/kota berisi materi muatan dalam rangka penyelenggaraan otonomi daerah dan tugas pembantuan serta menampung kondisi khusus daerah dan/atau penjabaran lebih lanjut dari peraturan perundang-undangan yang lebih tinggi.

Sesuai asas desentralisasi, daerah memiliki kewenangan membuat kebijakan daerah untuk mengatur urusan pemerintahannya sendiri. Kewenangan daerah mencakup urusan pemerintahan konkuren yang terdiri atas urusan pemerintahan wajib dan urusan pemerintahan pilihan yang diatur dalam Undang-undang Nomor 23 Tahun 2014 tentang pemerintahan daerah. Peraturan daerah dilarang bertentangan dengan kepentingan umum dan/atau peraturan perundang-undangan yang lebih tinggi. Dalam konteks ini, yang dimaksudkan bertentangan dengan kepentingan umum adalah kebijakan yang mengakibatkan terganggunya kerukunan warga, pelayanan umum, dan ketertiban/ketenteraman masyarakat, serta kebijakan/peraturan daerah yang bersifat diskriminatif serta berorientasi pada kebutuhan masyarakat.

Ketentuan di atas menjadi dasar bagi pemerintah untuk melakukan pengawasan preventif dan represif terhadap peraturan daerah. Pengawasan tersebut dimaksudkan agar peraturan daerah tetap berada dalam kesatuan hukum nasional. dari segi hierarki peraturan perundang-undangan, materi muatan peraturan perundang-undangan tidak boleh bertentangan dengan peraturan yang lebih tinggi. Proses harmonisasi vertikal menjadi sangat penting dalam proses pembentukan peraturan perundang-undangan, sehingga materi muatannya dapat sejalan dengan asas hukum lex superiori derogate lex inferiori.

Kota Banjarmasin saat ini perkembangan antara pertumbuhan penduduk dan kebutuhan tanah tidak seimbang. Hal ini menyebabkan perkembangan permukiman yang terjadi tidak hanya perumahan secara legal, tetapi juga pemanfaatan lahanlahan kosong secara ilegal oleh masyarakat, seperti lahan di bantaran/sempadan sungai. Bantaran/sempadan sungai dimanfaatkan oleh orang-orang yang berdomisili di daerah setempat sebagai sebagai pelebaran rumah atau dimanfaatkan 
untuk bangunan usaha tertentu yang selama ini dilakukan turun-temurun dari orang tua mereka. Hal ini tentunya sangat mengganggu fungsi dan kegunaan sempadan sungai sebagai sarana ruang terbuka hijau dan fungsi pengairan untuk pelaksanaan pengerukan dasar sungai secara rutin. Situasi dan kondisi ini semakin meluas karena belum ada suatu tindakan untuk penertiban terhadap kawasan sempadan sungai tersebut. Oleh karena itu, sejalan dengan kebijakan otonomi daerah yang memberikan kewenangan semakin besar kepada pemerintah daerah provinsi dan kabupaten/kota dalam penyelenggaraan penataan ruang, maka kewenangan tersebut sangat penting untuk menjaga keserasian dan keterpaduan antar daerah dan antara pusat dan daerah agar tidak menimbulkan kesenjangan antar daerah. Keberadaan ruang yang terbatas dan pemahaman masyarakat yang berkembang terhadap pentingnya penataan ruang memerlukan penyelenggaraan penataan ruang yang transparan, efektif, dan partisipatif, agar terwujud ruang yang aman, nyaman, produktif, dan berkelanjutan.

Pasal 18 Undang-undang Nomor 26 Tahun 2007 tentang Penataan Ruang mengatur bahwa penetapan rancangan peraturan daerah provinsi atau kabupaten/kota tentang rencana tata ruang wilayah provinsi atau kabupaten/kota dan rencana rinci tata ruang terlebih dahulu harus mendapat persetujuan substansi dari menteri. Ketentuan mengenai pedoman pemberian persetujuan substansi dalam rangka penetapan Peraturan Daerah tentang Rencana Tata Ruang Provinsi dan Rencana Tata Ruang Kabupaten/Kota diatur dengan Peraturan Menteri Agraria dan Tata Ruang/Kepala Badan Pertanahan Nasional Nomor 8 Tahun 2017. Dalam rangka konservasi sungai, pengembangan sungai, dan pengendalian daya rusak air sungai, ditetapkan Peraturan Pemerintah Nomor 38 Tahun 2011 tentang Sungai. Pasal 30 mengatur bahwa pengembangan sungai melalui pemanfaatan sungai dilakukan dengan tidak merusak ekosistem sungai, mempertimbangkan karakteristik sungai, kelestarian keanekaragaman hayati, serta kekhasan dan aspirasi daerah/masyarakat setempat.

Kalimantan Selatan merupakan salah satu provinsi di Indonesia yang memiliki banyak sungai sebagai salah satu sumber daya alamnya. Sungai terbesar dan terpanjang di Kalimantan Selatan adalah Sungai Barito, yang mata airnya berasal dari pedalaman Kalimantan Tengah dan bermuara ke Laut Jawa. Sungai Barito mempunyai banyak anak sungai, dan wilayah di sepanjang aliran sungai ini sejak jaman dulu telah menjadi tempat konsentrasi pemukiman penduduk. Oleh karena itu, sejak dulu lokasi kota-kota banyak yang berada di sekitar muara sungai atau tepi pantai. ${ }^{18}$ Daerah tepian sungai merupakan wilayah yang sangat subur karena endapan lumpur akibat pengaruh pasang surut air sungai. Oleh karena

18 Rochgiyanti, "Fungsi Sungai Bagi Masyarakat Di Tepian Sungai Kuin Kota Banjarmasin,” Jurnal Komunitas: International Journal of Indonesian Society and Culture 3, no. 1 (2011): 52, https://doi.org/https://doi.org/10.15294/komunitas.v3i1.2293. 
kesuburan tanahnya, maka wilayah tepian sungai menjadi tempat konsentrasi penduduk. Di samping Sungai Barito dan anak-anak sungainya, juga banyak ditemukan sungai buatan atau kanal yang disebut anjir, handil, dan saka. Begitu pentingnya sungai bagi masyarakat Kalimantan Selatan, sehingga berkembang suatu budaya sungai, yang berpengaruh pada hampir setiap kehidupan masyarakatnya. ${ }^{19}$ Sehingga berkenaan dengan hal tersebut pemerintah Kota Banjarmasin kemudian mengeluarkan Peraturan Daerah Nomor 31 Tahun 2012 tentang Penetapan, Pengaturan, Pemanfaatan Sempadan Sungai dan Bekas Sungai, yang mengatur tentang garis batas sempadan sungai yang digunakan sebagai pelestarian fungsi sungai, mengingat budaya sungai tidak dapat dipisahkan keberadaannya dari masyarakat setempat, sehingga diperlukan upaya-upaya untuk pelestarian budaya sungai tersebut.

Sesuai dengan kondisi geografisnya, maka rumah-rumah penduduk dibangun di atas tiang-tiang di tepi sungai, atau di atas sungai. Rumah-rumah penduduk dibangun dari kayu hutan yang banyak terdapat di wilayah Kalimantan Selatan. Semula rumah-rumah dibangun di tepian sungai, menghadap ke arah sungai sehingga sungai menjadi halaman depan. Berbeda dengan sungai-sungai di pekotaan besar, dimana terdapat banyak kegiatan domestik masyarakat yang berkaitan dengan sungai, seperti mandi, cuci, kakus. Hal ini menggambarkan bagaimana sungai bukan sebagai hal yang vital dalam kehidupan. Sungai dianggap sebagai halaman belakang, karena itu muncul perilaku yang berkaitan dengan fungsi sungai yang dianggap sebagai backyard seperti kebiasaan membuang kotoran dan sampah lebih. ${ }^{20}$

Menurut deskripsi Kertodipoero tentang sungai dan pemukiman penduduk, di pahuluan Kalimantan rumah-rumah berdiri di atas tiang, semuanya menghadap ke sungai, dan masing-masing rumah mempunyai batang-batang kayu (titian). Ia menyebut kampung-kampung yang berada di sepanjang tepian sungai sebagai sebuah "stasiun", yang menghubungkan satu kampung dengan kampung lainnya, dan setiap orang yang melewatinya bisa menyinggahinya. ${ }^{21}$ Sungai adalah bagian dari kehidupan bagi sebagian masyarakat di Provinsi Kalimantan Selatan yang wilayahnya didominasi oleh sungai, keberadaan sungai dipandang sebagai urat nadi kehidupan khas bagi masyarakat setempat. Sungai sudah menjadi wadah aktivitas utama masyarakat sejak dahulu hingga sekarang, utamanya dalam bidang perdagangan dan transportasi.

Beberapa daerah di kabupaten/kota di Provinsi Kalimantan Selatan tata kehidupannya didominasi oleh sungai. Sebagaimana Kota Banjarmasin sebagai pusat ibukota Provinsi Kalimantan Selatan sendiri, di mana sungai-sungai yang ada

\footnotetext{
19 Rochgiyanti.

20 Rochgiyanti.

21 Rochgiyanti.
} 
membelah Kota Banjarmasin menjadi magnet ekonomi, khususnya perdagangan dan pariwisata. Data dari Dinas Kimprasko Banjarmasin menunjukkan pada tahun 1997 di ibukota Provinsi Kalimantan Selatan terdapat 117 sungai, sedangkan pada tahun 2002 berkurang menjadi 70 sungai, dan sejak tahun 2004 sampai dengan sekarang berkurang menjadi 60 sungai saja. Bagi warga Kota Banjarmasin, sungai adalah fitur alami dan integritas ekologis yang berguna bagi ketahanan hidup. Sungai sebagai salah satu sumber air mempunyai fungsi yang sangat penting bagi kehidupan dan penghidupan masyarakat. Peraturan Pemerintah Nomor 35 Tahun 1991 tentang Sungai, menyatakan sungai merupakan tempat dan wadah serta jaringan pengaliran air mulai dari mata air sampai muara, dengan dibatasi kanan dan kirinya serta sepanjang pengalirannya oleh garis sempadan.

Perkembangan kota dan meningkatnya jumlah penduduk menyebabkan pemukiman baru berkembang hingga di sepanjang sungai. Hal demikian tentu menyebabkan sungai dapat kehilangan fungsinya serta kualitas lingkungannya juga menurun. Banyaknya perkampungan dan pemukiman yang dibangun di sepanjang sungai menyebabkan sungai beralih fungsi, menjadi sempit, kotor dan banyak sampah. Sempadan sungai dapat dikatakan juga sebagai kawasan rawan bencana yang sangat berbahaya bagi masyarakat apabila dimanfaatkan sebagai kawasan pemukiman, perdagangan, serta peruntukkan budidaya lainnya demi pembangunan dan pendapatan asli daerah. Sayangnya, manfaat atau fungsi sempadan sungai tersebut masih kurang mendapatkan perhatian oleh pemerintah daerah.

\section{PENUTUP}

Di Indonesia, sungai dapat dijumpai hampir pada setiap daerah. Sungai menjadi tumpuan hidup bagi masyarakat yang berdiam di sekitar alirannya, baik untuk keperluan transportasi, mandi, mencuci, dan aktivitas ekonomi. Untuk wilayah tertentu seperti di Provinsi Kalimantan Selatan khususnya Kota Banjarmasin, sungai bahkan dapat menunjang kebutuhan utama masyarakat yang berdampak pada sistem perekonomian masyarakat, serta dalam skala global turut mempengaruhi pembangunan nasional. Untuk kepentingan kelestarian sungai, serta agar sungai dapat berfungsi dan memberi nilai ekonomis bagi penduduk khususnya yang berada di sekitar, Pemerintah Kota Banjarmasin telah memberlakukan Peraturan Daerah Nomor 31 Tahun 2012 tentang Penetapan, Pengaturan, Pemanfaatan Sempadan Sungai dan Bekas Sungai. Terjadinya alih fungsi lahan sempadan sungai menjadi permukiman penduduk disebabkan ketidaktahuan masyarakat tentang ketentuan-ketentuan mendirikan bangunan di kawasan sempadan sungai. Beberapa rekomendasi dari penelitian ini adalah revisi terhadap pengaturan kawasan sempadan sungai, memprioritaskan perlindungan sempadan sungai di Kota Banjarmasin khususnya pada kawasan yang rawan tekanan perkembangan permukiman penduduk dan kawasan sempadan sungai yang masih alami dan melakukan status quo pada kawasan sempadan sungai yang telah menjadi 
permukiman. Sebelum itu juga perlu dilakukan kajian tentang sungai dan penetapan garis sempadan sungai dengan mempertimbangkan karakteristik geoformologi sungai serta kondisi sosial budaya masyarakat. Bagi masyarakat Banjarmasin sendiri perlu mendapatkan sosialisasi dan edukasi mengenai kebijakan dan pengaturan tentang perlindungan kawasan sempadan sungai, agar kedepannya impelementasi Perda dapat berjalan efektif dengan tetap memperhatikan faktor sosial budaya masyarakat Banjarmasin namun dapat mengurangi potensi terhadap dampak lingkungan.

\section{DAFTAR PUSTAKA}

Afdholy, Amar Rizqi. "Tipomorfologi Permukiman Tepian Sungai Martapura Kota Banjarmasin.” Local Wisdom : Jurnal Ilmiah Kajian Kearifan Loka 9, no. 1 (2017): 34https://jurnal.unmer.ac.id/index.php/lw/article/. https://doi.org/https://doi.org/10.26905/lw.v9i1.1865.

Afdholy, Amar Rizqi, Hamka, and Sri Winarni. "Tipologi Pola Tata Letak Rumah Pada Permukiman Tepian Sungai Kota Banjarmasin." Pawon: Jurnal Arsitektur 5, no. 01 (2021).

Agoes, Herliyani Farial. "Studi Inventarisasi Sungai Yang Tidak Produktif Di Kota Banjarmasin." Jurnal INTEKNA: Informasi Teknik Dan Niaga 11, no. 2 (2011): 158.

Bunga, Marten. "Model Pembentukan Peraturan Daerah Yang Ideal Dalam Penyelenggaraan Otonomi Daerah." Jurnal Hukum dan Pembangunan 49, no. 4 (2019).

Caesarina, Hanny Maria, and Dienny Redha Rahmani. "Persepsi Masyarakat Lokal Terhadap Ruang Terbuka Hijau Pada Kota Berbasis Sungai" EnviroScienteae 16 no. 3 (2020). http://dx.doi.org/10.20527/es.v16i3.9679.

Darwance, D, Yokotani, and Wenni Anggita. "Politik Hukum Kewenangan Pemerintah Daerah Dalam Pengaturan Hak Kekayaan Intelektual." Journal of Political 2 no. 2 (2021). https://doi.org/10.33019/jpi.v2i2.40.

Effendy, Mohammad. " Perlindungan Hukum terhadap Lahan Basah yang menjadi Area Perkebunan Sawit di Kabupaten Hulu Sungai Utara." Banua Law Review 2, no. 1 (2020). https://doi.org/10.32801/balrev.v2i1.10.

Firdaus, Muhammad Ananta. "Pelaksanaan Peraturan Daerah Tentang Larangan Kegiatan Pada Bulan Ramadhan Di Kota Banjarmasin.” Badamai Law Journal 3, no. 1 (2018): 132.

Gandara, Moh. "Kewenangan Atribusi, Delegasi Dan Mandat." Khazanah Hukum 2, no. 3 (2020).

Hadinata, Irwan Yudha, and Bani Noor Muchamad. "Studi Penyusunan Dan Penentuan Sempadan Sungai Di Kota Banjarmasin." Jurnal Kebijakan Pembangunan 13, no. 1 (2018): 5.

HS, Salim, and Elis Septiana Nurbani. Penerapan Teori Hukum Pada Penelitian Tesis Dan Disertasi. Jakarta: PT Rajagrafindo Persada, 2013.

Manan, Bagir. "Wewenang Provinsi, Kabupaten, Dan Kota Dalam Rangka Otonomi Daerah." In Seminar Nasional, 1-2. Bandung: Fakultas Hukum 
Universitas Padjajaran, 2000.

Maulina, Novaria, and Atika, "Komunikasi Lingkungan Melalui Maharagu Sungai Dalam Meningkatkan Partisipasi Masyarakat Pada Program Revitalisasi Sungai Kota Banjarmasin." Metacommunication: Journal Of Communication Studies 6, no. 1 (2021). http://dx.doi.org/10.20527/mc.v6i1.10127.

Mentayani, Ira. "Identitas Dan Eksistensi Permukiman Tepi Sungai Di Banjarmasin." In Prosiding Seminar Nasional Lingkungan Lahan Basah, 498. Banjarmasin: Lembaga Penelitian dan Pengabdian kepada Masyarakat, Universitas Lambung Mangkurat, 2019.

Pradana, Herry. "Pengembangan Pariwisata Pasar Terapung Kota Banjarmasin." Jurnal Kebijakan Pembangunan 15 no. 1 (2020). https://doi.org/10.47441/jkp.v15i1.56.

Rochgiyanti. "Fungsi Sungai Bagi Masyarakat Di Tepian Sungai Kuin Kota Banjarmasin." Jurnal Komunitas: International Journal of Indonesian Society $\begin{array}{llllll}\text { and } \quad \text { Culture } & 3, & \text { no. } & 1 & \text { (2011): } & 52 .\end{array}$ https://doi.org/https://doi.org/10.15294/komunitas.v3i1.2293.

Sunarno, Siswanto. Hukum Pemerintahan Daerah. Jakarta: Sinar Grafika, 2006.

Syamsudin, Aziz. Proses Dan Teknik Perundang-Undangan. Jakarta: Sinar Grafika, 2011.

Tjandra, W. Riawan, and Kresno Budi Harsono. Legislatif Drafting Teori Dan Teknik Pembuatan Peraturan Daerah. Yogyakarta: Universitas Admajaya, 2009. 